\title{
PSAETERZ DAWIDÓW (KSIĘGA SŁOWIAŃSKA) \\ ORAZ ELEMENTARZ ETYCZNY KAROLA WOJTYŁY JAKO PRZEJAWY KOMUNIKOWANIA IDEI I WARTOŚCI
}

Celem artykułu jest ustalenie tego, czy przesłanie ideowe tekstów literackich Karola Wojtyły koresponduje z refleksją filozoficzną Autora Osoby i czynu. Zostaną omówione wybrane idee oraz wartości, które inspirowały wczesną literacką oraz późniejszą filozoficzno-teologiczną twórczość Wojtyły. Przedmiotem analizy będzie Psatterz Dawidów (Księga stowiańska) z 1939 roku oraz Elementarz etyczny powstały na podstawie felietonów publikowanych na łamach Tygodnika Powszechnego w latach 1957-1958. Przesłankami do podjęcia tytułowego zagadnienia są: silne nacechowanie ideowo-aksjologiczne utworów literackich Wojtyły (na ten temat por. Przestrzeń słowa); fakt, że idee i wartości stanowią istotny element dorobku Autora Hioba (Wojtyła, Rozważania o istocie człowieka), jak również Magisterium Pontificium Jana Pawła II (na ten temat - por. Drożdż 11-53; Dudziak, „Aksjologiczne aspekty komunikowania międzykulturowego Jana Pawła II" 120-142; Dudziak, „W kręgu komunikacji aksjologicznej św. Jana Pawła II” 49-59; Dudziak, „Aksjologiczne aspekty komunikowania św. Jana Pawła II w orędziach” 198-209).

W wymiarze metodologicznym niniejszych rozważań do diagnozy idei posłuży hermeneutyka (Ricoeur Egzystencja i hermeneutyka; Ricoeur, Język, tekst, interpretacja; Ricoeur, O interpretacji), zaś do charakterystyki aksjosfery Wojtyły zostanie zastosowana analiza aksjolingwistyczna (Łabaszczuk 9-18; Leszczak 35-65).

Dr hab. ARKADIUSz DudZIAK - adiunkt Katedry Komunikacji Społecznej, pracownik Instytutu Dziennikarstwa i Komunikacji Społecznej Uniwersytetu Warmińsko-Mazurskiego w Olsztynie; adres do korespondencji: ul. Kurta Obitza 1; 10-725 Olsztyn; e-mail: arkadiuszdudziak@interia.pl. ORCID: http://orcid.org/0000-0002-5397-4023. 
W niniejszych rozważaniach używa się terminów: „wartości dodatnie” (to, co powinno być), „wartości ujemne” (,,antywartości” - to, co powinno nie być). Przez niektórych humanistów wyrażenia te mogą być uznawane za pleonazm i oksymoron. Jednak do zastosowania owej terminologii upoważnia stan badań w aksjologii (Elzenberg 23; Hostyński 36), jak również w aksjolingwistyce (Puzynina 180).

Niniejsze wywody zostały oparte na aksjologicznej koncepcji Zbigniewa Chojnowskiego, zgodnie z którą poezja jest komunikacją ideową, mową idei konstytuowaną przez wartości. Poezja transmituje idee i wartości, praktykuje wartości poprzez język. Poezja wypracowuje i demistyfikuje idee, jak również nadaje i odwołuje wartości (Chojnowski 209-210).

\section{IDEE I WARTOŚCI OBECNE W JUWENILIACH KAROLA WOJTYŁY}

W wierszu Nad Twoja biała mogita, pierwszym utworze poetyckiego cyklu Karola Wojtyły z 1939 roku zatytułowanego Renesansowy psałterz (Księga stowiańska) (Wojtyła, Poezje, dramaty, szkice 27; w wydaniu: Wojtyła, Dzieła literackie i teatralne 1: 41 - cykl nosi tytuł Psalterz Dawidów (Księga stowiańska)), w apostrofach do nieżyjącej matki, Emilii, przejawia się idea bytu pośmiertnego pojmowanego jako istota duchowa: „bez Ciebie - duchu skrzydlaty”.

W utworze tym są obecne dwojakie wartości:

a) dodatnie: życie, spokój, siła, nadzieja;

b) ujemne (antywartości): śmierć, smutek, bezsilność.

W analizowanym tekście występują nie tylko wartości implikowane przez elementy systemu językowego, środki leksykalne, których semantyka wiąże się bezpośrednio z określoną informacją aksjologiczną, jak np. nazwy wartości czy antywartości: życie, śmierć. Komunikację poetycką Wojtyły charakteryzuje również językowe zjawisko wartościowania, tj. oceniania obiektów, zjawisk, stanów rzeczy etc. według jakiegoś kryterium aksjologicznego, np. kategorii dobro / zło (na temat językowych uwarunkowań wartościowania - por. Laskowska 19; Kurczab 7-37; Kiklewicz 40-48). Sposób poetyckiego wartościowania polega na przybieraniu znaczeń wartości przez pozasystemowe środki językowe. Występuje bowiem wartościowanie konotacyjne - informacja aksjologiczna nie jest związana bezpośrednio z semantyką leksykograficzną, lecz wynika z jakiegoś kontekstu i asocjacji. Interpretacja wartościowania konotacyjnego wymaga od odbiorcy komunikatu rekonstrukcji znaczenia poprzez czerpanie informacji z zasobów wiedzy kulturowej, historycznej, biograficznej itp. (Benenowska, „Środki implikujące wartościowanie w wolitywnych aktach mowy” 12-13). W taki sposób wartość miłości nie funkcjonuje w tekście explicite (nie została wymieniona rzeczownikowo jako nazwa), ale jest konotowana przez wyra- 
żenie „o Matko - zgasłe kochanie”. Krąg ewentualnych asocjacji poszerza jeszcze zasób potencjalnego wartościowania w taki sposób, że przytoczone wyrażenie może nabierać charakteru informacji aksjologicznej w znaczeniu wartości tęsknoty za zmarłą, wartości nostalgii z powodu śmierci matki etc. Zjawisko wartościowania konotacyjnego dotyczy też innych, wymienionych w tekście, środków językowych: „mogiłą”, „,duchu skrzydlaty”, „życia kwiaty”, „cisza jasna promienieje”,, ,krzepiło nadzieję", „usta szeptały bezsiłą". Wydobycie sensu możliwe jest przez odniesienie do systemu wartości uwarunkowanego kontekstem kulturowym (na temat wartościowania konotacyjnego - zob. Benenowska, Wartościowanie w listach Marii Pawlikowskiej-Jasnorzewskiej 185). Jak czytamy w Hermeneutyce Arystotelesa: „Słowa są symbolicznymi znakami wrażeń doznawanych” (Arystoteles 11); „Każda wypowiedź coś znaczy, ale nie jako narzędzie, lecz na mocy umowy" (Arystoteles 13).

Podmiot liryczny traktuje mogiłę jako nacechowane sakralnie miejsce wiecznego odpoczywania. Wartość spokoju jest odczuwana przez podmiot liryczny jako tajemnicza siła. Antynomią wartości dodatniej spokoju przeciwstawiona jest - w stylistycznej figurze porównania - wartość ujemna śmierci: „spokój krąży z dziwną siłą, z siłą, jak śmierć - niepojętą".

Uzasadnienie dla hermeneutyki w duchu symbolicznym znajduje się we fragmencie tekstu zatytułowanego Do sonetów!: „Kiedy owe symbole mówić zaczęły do duszy młodej, kiedy domagać się zaczęły - czego? czego? - Wyzwolenia, śpiewności tęsknej, prorokowania" (Wojtyła, Dzieta literackie i teatralne 1: 61).

W aspekcie hermeneutycznym pierwszy utwór Księgi słowiańskiej zawiera przesłanie ideowe na temat spirytualistycznej wizji człowieka. Dominantę ideową tekstu stanowi wiara podmiotu w możliwość bezpośredniej relacji komunikacyjnej, dialogicznej ze zmarłą kochaną osobą. Świadczy o tym nie tylko dedykacja: „+ Emilii, Matce mojej” (Wojtyła, Poezje, dramaty, szkice 27), lecz także retoryczna dyspozycja utworu, tj. kompozycja pięciokrotnej apostrofy ze zwrotami osobowymi: „Nad Twoją...”, „,bez Ciebie”, „o Matko”.

Interpretacja tekstu pozwala ujawnić również ideę obecności, tj. doświadczanie przez podmiot komunikujący jedności czasoprzestrzennie oddalonych od siebie rzeczywistości. Podmiot liryczny doświadcza obecności ducha zmarłej matki. Podstawą owej obecności jest jedność dana między osobami na mocy jednoczącego poznania i miłości („o Matko - zgasłe kochanie”) (na temat kategorii obecności w teologii chrześcijańskiej - zob. Rahner, Vorgrimler 281). Wiersz Wojtyły prezentuje idę communio sanctorum. Obcowanie świętych przejawia się w przekonaniu podmiotu lirycznego o jedności z osobą, która już nie żyje. Dodatkowo osobie tej nadaje podmiot atrybuty anielskie („duchu skrzydlaty”), co jest charakterystyczne dla chrześcijańskich wyobrażeń obcowania i kultu świętych. Ponadto w działaniu podmiotu 
obecna jest też idea wstawiennictwa poprzez modlitwę i czyn: „Daj wieczne odpoczywanie" (na temat pojęcia obcowania świętych - zob. Rahner, Vorgrimler 281).

Kolejną sferą hermeneutyki rozpatrywanego tekstu Wojtyły jest idea zbawczej woli Boga względem ludzi i aniołów, jako stwórcy, prawodawcy, udzielającego nadprzyrodzonej łaski. Królestwo Boże, jako dar udzielany i urzeczywistniany, musi być wymodlone. Jest to zadanie powierzone człowiekowi, dlatego spełnia je podmiot liryczny. Łaska zbawienia, królestwa Bożego, jest w teologii przedmiotem nadziei: ,jakby krzepiło nadzieję".

Podmiotowi lirycznemu przyświeca idea pokonania doznań afektywnych - smutku i poczucia bezsilności: „klęknąłem ze swoim smutkiem [...] me usta szeptały bezsiłą". Sposobem przezwyciężenia tęsknoty za nieżyjącą osobą jest wyzwoleńcze, kontemplacyjne doznawanie spokoju i ciszy oraz krzepiącej nadziei (łaski, zbawienia, królestwa Bożego) odczuwanej jako siły krążenia, promieniowania i wznoszenia się. W teologii chrześcijańskiej człowiek, doznając własnej niemocy, rozpoznaje sposób, w jaki nadchodzi moc Boża, zbawcza wola Boga (Rahner, Vorgrimler 196):

$$
\begin{aligned}
& \text { spokój krąży z dziwną siłą, } \\
& \text { Z siłą, jak śmierć - niepojętą. } \\
& {[\ldots] \text { cisza jasna promienieje, }} \\
& \text { jakby w górę coś wznosiło. }
\end{aligned}
$$

Owe doznania podmiotu lirycznego można zinterpretować również jako ideę, że człowiek jest istotowo osobową samotranscendencją ku temu, co wyższe. Realizuje się jako bezinteresowna miłość, życzliwość - amor benevolentiae. Nadzieja, wiara - jako przejawy działań duchowych człowieka - są ożywiane przez miłość (Rahner, Vorgrimler 235).

W sonecie „I List do Przyjaciela” przejawia się idea poezji natchnionej:

\footnotetext{
W tych sobótkach się serca sprzęgają

Utajonych płomieni węzłami.

Poezja jest ukojeniem - sobótek córa.
}

Ekwiwalentem poezji natchnionej w opinii Zbigniewa Chojnowskiego jest „odkrywanie nowych punktów widzenia, czynienie nieważnego ważnym, niewidzialnego widzialnym, niedostrzeżonego dostrzeżonym" (na temat istotowej odrębności języka poetyckiego jako sposobu komunikowania się nadawcy z adresatem - zob. Chojnowski 213).

W poetyckim świecie wartości owego utworu napotykamy konotację estetycznej wartości piękna: 
Madohorze się kłaniaj ode mnie

$\mathrm{Z}$ poszarpanemi sosnami!

Ładnie dziś u Was - w górach! (Wojtyła, Dzieła literackie i teatralne 1: 43)

Ideowe przesłanie sonetu „II List do Przyjaciela” dotyczy roli poety w społeczeństwie i jego podmiotowości:

\footnotetext{
Mostami - drogami - cierniami - na co dzień

Ludzkość spętanym skrzydłom nie złoży obiaty -

Lecz oto jest poeta - artysta: kołodziej -

Niech rzuci mosty i drogi przez kwiaty!
}

Poeta, utożsamiany z podmiotem lirycznym, jest tym, kto w obliczu antywartości niewoli (implikowanej poetycką figurą „,spętanym skrzydłom”) przeciwstawi wartość wolności - symbolizowaną przez frazę „,mosty i drogi przez kwiaty”.

Dodatkowym aspektem semantycznym rozpatrywanego komunikatu poetyckiego jest idea dialogiczności. Dialogiczność przejawia się na poziomie językowym w apostrofach:

- Ten list - Drogi - do Ciebie, bo z Tobą się dzielę;

- Na wieczór ten lipowy wspomnij, jak ja pomnę -

Wspomnij na pierwszą moich słów wiązankę;

- Pamiętaszże? [...] wszak pomnisz?

Inną ideą utworu jest afirmacja rozwoju człowieka, implikowana wartością „Dążeń”, czyli celów, intencji, preferencji, marzeń, wyobrażeń w zakresie rozwoju podmiotu jako osoby - rozwoju: emocjonalnego, intelektualnego, moralnego, duchowego etc.:

Tedy wznosić poczynam młodzieńczy most Dążeń -

Budowla kaskadami upiętrzona w górę.

[...] Pamiętaszże? - Już wtedy ten takt marzeń kułem...

(Wojtyła, Dzieła literackie i teatralne 1: 45)

Symboliczna budowla „mostu Dążeń” konotuje - na poziomie hermeneutyki tekstu - wartość budowania (Kościoła, eschatologicznego królestwa - basilei) lub też eklezjologicznego budowania wspólnotowości i umacniania innych ludzi w opozycji do antywartości burzenia, np. świątyni w NT i jej odbudowania - Mt 16,18; Mt 26,60 (na temat pojęcia „budowania” - zob. Rahner, Vorgrimler 45). Metafora „most Dążeń” w wymiarze hermeneutycznym odsyła do ontologicznego pojęcia „celu” w transcendentnym akcie poznania. Pojęcie to dotyczy „etyki istoty” (etyki celu), wiąże się z takimi zagadnieniami teologicznymi, jak: nadnaturalny cel człowieka, Opatrzność, świat stworzony na chwałę Bożą (Rahner, Vorgrimler 47). 
W tematyce cyklu poetyckiego Karola Wojtyły Psałterz Dawidów przewija się idea cierpienia. W sonecie „III List do Przyjaciela” czytamy:

Korzeniem soków sięgnij! - Kroplami się sączą w konary

Ukrzyżowane cierpieniem, a w każdej kropli jest ból.

Matki powiedzą ciężarne, że ból się w serca zarył...

[...] Czemu jest w ziemi boleść?

[...] i ból jej z naszych jest bólów: w jedno stopiony kruszec.

(Wojtyła, Dzieła literackie i teatralne 1: 46)

Ziemia, niwa w odczuciu podmiotu lirycznego jest symbolem cierpienia, gdyż jest siedzibą Ukrzyżowanego - „Tabernakulum ziemi”. W sonecie „III List do Przyjaciela" współodczuwanie cierpienia ziemi, jako miejsca obecności sacrum, nabiera charakteru metafizycznego doświadczenia osoby w jej relacji z naturą. Rozwinięciem tej idei jest modlitewny sonet „IV”, w którym podmiot liryczny zwraca się z prośbą do matki (matki Bożej?) o spotkanie (nawiedzenie), okazanie litościwego miłosierdzia ludziom i przyrodzie oraz uhonorowanie dusz ludzkich poprzez ich cierniowe ukoronowanie, czyli przydanie duszom atrybutów Zbawiciela w rezultacie współodczuwania cierpienia:

widzimy na co dzień, o matko - twój ból, nasz ból i twą wiarę.

Dusze nam uwieńcz laurem - cierniowym bólem,

- na jutrznię zejdź z nami przed ranem, na skiby pełne ziaren.

U widnokręgów nas potkaj, nad granicami błękitu -

I nad oraczem, nad siejbą, nad pokwitaniem się zlituj!

(Wojtyła, Dzieła literackie i teatralne 1: 47)

W sonecie „V” pobrzmiewa poetycko idea takiej relacji człowieka z naturą, która wyzwala w podmiocie potrzeby refleksji nad duszą i modlitwy (Wojtyła, Dzieła literackie i teatralne 1: 48). Rozwinięciem tej idei jest sonet „VI”, w którym podmiot liryczny, jako dusza-gotycka świątynia symbolizująca miłosierdzie Boga nad człowieczeństwem, zwraca się do Bóstwa, uosabiającego wartość Miłości, o zbawienie, eschatologiczne wyzwolenie z ciemności i cierpienia:

Najpotężniejszy Eli!

[...] O spłyń anielską jaśnią nad przepastne topiele!

Czasom przybliż Twą Miłość! Niechaj ciemności roztrąca!

W świątyniach wiosennych wyzwolin niechaj nie będzie udręczeń!

(Wojtyła, Dzieła literackie i teatralne 1: 49)

Tematem sonetu „VII List do Przyjaciela” (Wojtyła, Dzieła literackie i teatralne 1: 50) jest eschatologiczna wiara w odkupieńczą moc Zmartwychwstałego Chrystusa w rezultacie zjednoczenia dusz przeciwstawiających się Złu. Utwór reprezentuje 
aksjologię chrześcijańskiego humanizmu z ideą wolnej woli; ideą afirmacji życia; ideą intencjonalności, swobody działania zgodnie z własną wolą; ideowym przekonaniem, że człowiek świadomie poszukuje sensu i kieruje się wartościami (na temat idei i wartości humanistycznych - zob. Obacz 68-69).

Bogactwo aksjosfery Wojtyły-poety prezentują sonety „VIII” i „IX”: prawość, świętość, piękno, pokój, błogosławieństwo, miłość, wolność (Wojtyła, Dzieła literackie i teatralne 1: 51-52).

Tematem sonetu „X” jest refleksja nad prawdą ludzkiej duszy. Wyznaniom podmiotu lirycznego towarzyszy eschatologiczna wiara w zwycięstwo dobra nad złem w imię takich wartości, jak: sprawiedliwość, prawość:

Największą Prawdę ludzką odkrywam w tobie co dnia,

[...] w tobie - o duszo - taka się roztkliwia śpiewność, że wierzę w przemijanie najgorszych dni katorg, w jasność wierzę idącą z twojej wawelskiej gontyny,

[...] sprawiedliwości miarę i prawość dzierży czynów.

(Wojtyła, Dzieła literackie i teatralne 1: 53)

Ideą przewodnią sonetu „XI” jest wartość wolności. Podmiot liryczny wyraża mesjanistyczną potrzebę słowiańskiej odnowy eschatologicznej, płynącej z mocy wartości Miłości:

Duszo z wolności wyrosła, moc mesyjańską wyrzeźb i zaklnij w psalmy Miłości - w renesansowy psałterz! I powstań wcieleniem nowym - odwieczna Beatrycze drogę nam ku Miłości słowiańskim oświeć zniczem!

(Wojtyła, Dzieła literackie i teatralne 1: 54)

Dominantę aksjologiczną sonetu „XII” stanowią wartości ludzkiego szczęścia i miłości utożsamianej z radością i wiosną. Wartości te są rozpatrywane w kontekście chrystianistycznej historiozofii:

Na ścieżkach Chrystusowych - pod dębami zachwytów

O duszo czasów idących - jaśń twą ewangeliczną

ujrzałem w szlakach zórz od ziemi ku zenitom

[...] Wieczory idą kupalne. Weselem idą i wiosną.

Spod lip się można szczęściu ludzkiemu napatrzeć do syta.

Czerwień miłosna - kupalna... Góry w płomieniach posną,

jak posągi lechickich władyków, jak widma lepszych świtań.

[...] Pod dębinami przystań - Biały Gościu Upragnień gdy w wiatru błogosławieństwie pieśnią wzbiorą żagle.

(Wojtyła, Dzieła literackie i teatralne 1: 55) 
Chrześcijańską aksjosferę sonetu „XIII” konstytuują następujące wartości: Miłość, braterstwo, Słowo, przyjaźń oraz Duch Święty (,Języków świetlistych łuna”, „On”, „Ptak Gołębicy”).

Za ideę nadrzędną organizującą sytuacje liryczne w sonetach „I List do Przyjaciela”, „II List do Przyjaciela”, „III List do Przyjaciela”, „VII List do Przyjaciela”, „XIII List do Przyjaciela” oraz „XVII Do Przyjaciół” należy uznać braterstwo (Wojtyła, Dzieła literackie i teatralne 1: 43, 45, 46, 50, 56, 60). Interpretacja idei, a zarazem wartości braterstwa, jest możliwa poprzez odczytanie wartościowania tekstowego, doszukanie się nacechowania aksjologicznego w pewnych fragmentach tekstowych lub nawet w całych tekstach jako wartościotwórczych komunikatach-wizjach świata (na temat zjawiska wartościowania tekstowego - zob. Benenowska, „Środki implikujące wartościowanie w wolitywnych aktach mowy" 13; Benenowska, Wartościowanie w listach Marii Pawlikowskiej-Jasnorzewskiej 198). Braterstwo, konotowane przez wymienione teksty Wojtyły, dotyczy silnej więzi emocjonalnej podmiotu lirycznego z najbliższymi przyjaciółmi - ludźmi związanymi wspólną ideą, podobieństwem zainteresowań oraz wrażliwości etycznej i estetycznej (na temat etymologii terminu braterstwo - zob. Długosz-Kurczabowa 62).

Sonety „XIV” i „XV” są wieszczymi refleksjami skoncentrowanymi wokół humanistycznych idei braterstwa oraz jedności ludzkości - motywowanymi wartościami: Słowa, Miłości, ofiary Zbawiciela, Dobrej Nowiny, Arki Bożych Objawień (Wojtyła, Dzieła literackie i teatralne 1: 57-58).

Sonet „XVI” jest poetycką refleksją nad wartościami piękna i miłości („,Miłowania"). Przesłaniem ideowym utworu jest humanistyczna wiara w jedność ludzkości tęskniącej za Pięknem - pojmowanym nie jako wartość estetyczna, lecz jako wartość historiozoficzna czy też eschatologiczna (Objawienia, Zmartwychwstania):

Oto jest droga Piękna: z prometeańskich błyskawic

[...] Wierzę w zmartwychwstanie obłoków z pokładów mgieł,

co przesłaniają Tatr widok... na odsłonięcie czekam

owego ścian wzniesienia i na Objawień dzień -

bo wierzę w tęsknoty ludzkości topolom podobne i sosnom,

kolumnom podobne Piękna - i rezurekcjom - i wiosnom.

(Wojtyła, Dzieła literackie i teatralne 1: 59)

Sonet „XVII Do Przyjaciół” to poetyckie studium mesjanistycznego oczekiwania przyjaciół na ewangeliczne odrodzenie ludzkości w duchu Wolności i Miłości. Myśl przewodnią utworu współtworzą idee: afirmacji życia, braterstwa, mesjanizmu, aksjologicznej podmiotowości człowieka - przekonania, że wybory wartości (przyjaźni, miłości, wolności) ukierunkowują proces stawania się osoby: 


\footnotetext{
Wśród teatrum zniszczenia, na cezariańskim forum Żyjemy trzy kolumny, w ramionach architrawu, [...] w mit zapatrzone ludzkości, w trud kamienistej uprawy.

Wpośród rozwalin teatrum w kajdany zakutych wrót, nad posągami Wolności, Miłości zdeptanym marmurem wstajemy - o Przyjaciele - trzech ognisk żar i głód, kolumny wśród ruin forum zniszczenia zbratane bólem.

$\mathrm{Ku}$ Kapitolom Wolności, w oczekiwaniu wyzwolin, na święte iszczenie się mitu - mesyjańskiego profilu, na kondygnacjach teatrum wpatrzone w objawień Olimp.
}

(Wojtyła, Dzieła literackie i teatralne 1: 60)

Aksjosfera Psałterza Dawidów (Księgi słowiańskiej) zawiera, obok wartości kolektywnych, kulturowych - uwarunkowanych funkcjonowaniem twórcy w określonej wspólnocie językowej i tradycji antropologiczno-kulturowej (m.in. życie, miłość, szczęście, prawda, dobro, piękno, wolność, przyjaźń, braterstwo) - także wartości indywidualne, odzwierciedlające aksjologiczną wrażliwość oraz poetycką kreatywność poety (jak np.: powinność, asceza, miłosierdzie, sacrum natury, mesjanizm). Poetycka komunikacja językowa w juweniliach Karola Wojtyły potwierdza tezę Tadeusza Zgółki, wedle której język kreuje wartości i współtworzy świat wartości (Zgółka 109).

\section{IDEE I WARTOŚCI W ELEMENTARZU ETYCZNYM}

Aksjosfera humanizmu chrześcijańskiego, będąca źródłem inspiracji wczesnej poezji Karola Wojtyły, stała się również tematem rozważań moralno-filozoficznych w Elementarzu etycznym. Zagadnienie powinności, znane z sonetu „II” Psałterza Dawidów (w aspekcie kulturowej roli i historiozoficznej misji poety-wieszcza), jest treścią rozważań szóstej części Elementarza zatytułowanej Znaczenie powinności. Wojtyła-filozof uznawał pojęcie natury ludzkiej za kluczowe dla etyki chrześcijańskiej i realizmu filozoficznego. Jego zdaniem powinność wyrasta z rozumowego rozeznania dróg doskonalenia się bytu ludzkiego w ramach całościowego porządku bytów. Rozum, jako władza natury ludzkiej, określa powinność, która czerpie swą energię z woli człowieka, dynamiki bytu ludzkiego, z „pędu do dobra”. Powinność moralna ma ścisły związek z ludzką wolą. Wola reprezentuje człowieczeństwo w aspekcie moralnego być albo nie być. Powinność odpowiada za linię napięcia pomiędzy tym, kim człowiek jest, a tym, kim być powinien (Wojtyła, Elementarz etyczny 37). W etycznej koncepcji przyszłego Papieża-Polaka moralność znajduje uzasadnienie teocentryczne, w wyniesieniu natury ludzkiej do porządku nadprzyrodzonego, zespoleniu natury człowieka z łaską Boga w pełnię ładu: 
człowiek pozostaje w takim odniesieniu do Boga, w jakim powinien, będąc Jego stworzeniem i dzieckiem zarazem, przy czym to odniesienie stawia go niejako dokładnie na właściwym miejscu w całym porządku bytów [...] nosi też człowiek pełnię ładu w sobie. Ciało nie jest oporne i niepodległe duszy, a nade wszystko wszystkie niższe energie natury doskonale ulegają wyższym. W człowieku panuje odpowiednie uduchowienie, rozum i wola nie są w defensywie, ale rządzą i kierują - ten ostatni współczynnik stanu doskonałości natury ludzkiej posiada zasadnicze znaczenie dla moralności. (Wojtyła, Elementarz etyczny 39)

W ujęciu Wojtyły cel ludzkiej natury jest stricte etyczny. Tym celem jest prawdziwe dobro, dobro moralne. Warunkiem umożliwiającym osiąganie dobra moralnego jest pełnia człowieczeństwa (status naturae integrae) - taki stan natury ludzkiej, który jest efektem dojrzałego zespolenia łaski Boga (łaski uświęcającej) z rozumem i wolą człowieka. Przypadek natury upadłej, zepsutej (status naturae lapsae) zachodzi wtedy, gdy następuje utrata łaski uświęcającej albo władzę nad człowiekiem tracą rozum i wola. Natura ludzka nie musi funkcjonować w stanie upadłym. Możliwy jest bowiem stan odkupienia (status naturae reparatae) - wariant, w którym rozum i wola człowieka doznają pomocy płynącej z dzieła odkupienia Jezusa Chrystusa. W takim przypadku natura ludzka podlega odbudowie zgodnej z pierwotnymi zamierzeniami Boga, doznając nowych „impulsów łask” (Wojtyła, Elementarz etyczny 39). W przekonaniu etyki katolickiej każdy normalny człowiek przeżywa powinność moralną. Wola motywuje człowieka do doznawania powinności jako stanu napięcia pomiędzy tym, kim się jest, a tym, kim się powinno być. Wolę zobowiązuje dobro moralne poznawane rozumowo. Znamionuje to wydolność natury ludzkiej w kierunku dobra moralnego (Wojtyła, Elementarz etyczny 40).

Wartość prawdy, inspirująca wyznanie podmiotu lirycznego w sonecie „X” Księgi stowiańskiej, stała się przedmiotem rozważań Wojtyły z punktu widzenia etyki zorientowanej teocentrycznie, w której Bóg jest najwyższą instancją prawdy o dobru i złu moralnym. Filozof podjął polemikę z etyką świecką, stawiającą etyce religijnej zarzut demoralizowania człowieka w rezultacie determinowania życia moralnego według jakiejś gry, w której człowiek przestaje ufać własnym wyborom i osądom moralnym, próbując sprostać niezrozumiałym regułom łaski i zasadom miłosierdzia jakichś potęg nadprzyrodzonych. W tym kontekście etyka katolicka zaleca, aby człowiek, jako osoba obdarzona samostanowieniem w zakresie własnych czynów, polegał na sądzie własnego sumienia w zakresie oceny dobra i zła moralnego. Kluczem jest potrzeba głębokiego rozumowego samopoznania w zakresie sumienia, a także rzetelnego zaangażowania woli dla jej wysiłku w kierunku dobra moralnego. Wojtyła wyrażał przekonanie, że sąd Boga jest zasadniczo tożsamy z sądem ludzkiego sumienia. Jeśli nawet sąd sumienia okazałby się błędny, to Bóg w każdej chwili przenika ludzką istotę głębiej od ludzkiej samoświadomości sumienia. Bóg zna siłę zaangażowania woli człowieka ku dobru, w motywach działania oddziela pozory 
dobra od dobra prawdziwego. Sąd Boga jest ostatnią instancją prawdy o człowieku. Wyostrza i wysubtelnia sąd moralny człowieka (Wojtyła, Elementarz etyczny 52-53). Miłosierdzie - motyw poetycki z sonetów „IV” i „VI” Psatterza Dawidów inspirował również refleksje Wojtyły-filozofa zorientowane na etyczne kategorie: dobra, zła, sprawiedliwości:

Błędna jest także interpretacja miłosierdzia. Wedle nauki katolickiej żadne miłosierdzie, ani Boskie, ani ludzkie, nie oznacza zgody na zło, tolerowanie zła. Miłosierdzie jest zawsze związane z poruszeniem od zła ku dobru. Tam, gdzie ono zachodzi, zło efektywnie ustępuje. Gdzie zło nie ustępuje, tam nie ma miłosierdzia - [...] tam, gdzie nie ma miłosierdzia, nie ustapi zło. Zło bowiem samo w sobie, nie potrafi urodzić dobra. Dobro może być zrodzone tylko przez jakieś inne dobro. Otóż miłosierdzie Boga jest to właśnie Dobro, które rodzi dobro na miejscu zła. [...] Miłosierdzie Boga idzie ściśle w parze ze sprawiedliwością. W takim głębokim przeświadczeniu żyją ludzie autentycznie religijni. (Wojtyła, Elementarz etyczny 53-54)

Miłość to wartość często przejawiająca się w młodzieńczej poezji Wojtyły (w sonetach: „VI”, „VIII”, „IX”, „XI”, „XIII List do Przyjaciela”, „XXVI”, „XVII Do Przyjaciół"). W rozważaniach etycznych filozof zwrócił uwagę na fakt, że na miłości opiera się moralna nauka Chrystusa, czyli przesłanie ewangeliczne. Z miłością wiążą się takie wartości doznawane jako „przejawy serca”, jak: dobroć, oddanie, poświęcenie. Sprawiedliwość przejawia się rozsądkiem, stanowczością, surowością. Cnoty te pozwalają człowiekowi radzić sobie dobrze z życiem moralnym. Zdaniem Wojtyły miłość jest doskonalsza niż sprawiedliwość. Dla sprawiedliwości dobro jest przedmiotem dzielonym między osobami. W miłości dobro jest przedmiotem, który nie podlega podziałom i ograniczeniom (Wojtyła, Elementarz etyczny 84-85). Miłość jest swoistą energią pozwalającą przybliżyć się do osoby, wniknąć w jej świat, utożsamić się moralnie z jej bytem. Dążeniem miłości jest pragnienie jak największego dobra dla osoby miłowanej. Miłość potrafi wyzwolić w człowieku to, co najszlachetniejsze - wyzbycie się interesowności połączone z pragnieniem dobra w większym stopniu niż dla siebie samego (Wojtyła, Elementarz etyczny 86).

Istnieje ścisły związek idei i wartości obecnych w literackiej twórczości Karola Wojtyły z późniejszą refleksją księdza-filozofa-etyka. Przesłanie ideowe Psatterza Dawidów (Księgi stowiańskiej) koresponduje z elementami aksjologii chrześcijańskiego humanizmu obecnymi w Elementarzu etycznym. Artystyczna i filozoficzna wizja świata i człowieka w ujęciu Autora Człowieka i czynu była podporządkowana idei teocentryzmu, jak również antropologicznej koncepcji prymatu wartości duchowych. Autor skonstatował: 
Wyższość wartości duchowych nad materialnymi nie jest tylko sprawą jakiegoś irracjonalnego odczucia. Są one wyższe dlatego, że wiążą się z obiektywnie wyższym bytem, z bytem doskonalszym od materii. [...] Tak więc poznanie samo w sobie jest doskonałością rozumu, a moralność doskonałością woli. Tylko dla istot obdarzonych rozumem istnieje problem prawdy i tylko dla istot obdarzonych rozumną wolą istnieje problem dobra moralnego. Poza sferą duchową prawda i dobro moralne nie mają racji bytu. Ponieważ zaś trudno nie uznać, że są to wartości najwyższe wśród tych, jakimi żyje człowiek - zatem trudno nie uznać prymatu ducha. (Wojtyła, Elementarz etyczny 67)

Młodzieńcze sonety Wojtyły-poety oraz refleksje etyczne Wojtyły-filozofa, jako przejawy komunikowania idei i wartości, ujawniają teocentryczną orientację twórcy. Teocentryzm autora Rozważań o istocie człowieka nie potwierdza antropocentryzmu przypisywanego Janowi Pawłowi II przez Konrada Szocika (Szocik 217-230).

\section{BIBLIOGRAFIA}

Arystoteles. Hermeneutyka. Topiki. O dowodach sofistycznych. Przełożył, wstępem i komentarzem opatrzył Kazimierz Leśniak, Wydawnictwo Naukowe PWN, 2013.

Benenowska, Iwona. „Środki implikujące wartościowanie w wolitywnych aktach mowy na tle innych środków wartościujących (wybranych z listów Marii Pawlikowskiej-Jasnorzewskiej do męża)". Wartości i wartościowanie we wspótczesnej humanistyce. III: Perspektywa językoznawcza, red. Aleksander Kiklewicz, Jolanta Piwowar, Centrum Badań Europy Wschodniej UWM w Olsztynie, 2017, ss. 9-22.

Benenowska, Iwona. Wartościowanie w listach Marii Pawlikowskiej-Jasnorzewskiej. Wydawnictwo Uniwersytetu Kazimierza Wielkiego, 2015.

Chojnowski, Zbigniew. „Idee i wartości poezji oraz poezja o ideach i wartościach”. Idee $i$ wartości w języku i kulturze, red. nauk. Iza Matusiak-Kempa, Alina Naruszewicz-Duchlińska, Instytut Filologii Polskiej Uniwersytetu Warmińsko-Mazurskiego w Olsztynie, 2015, ss. 209-222.

Długosz-Kurczabowa, Krystyna. Wielki stownik etymologiczno-historyczny języka polskiego. Wydawnictwo Naukowe PWN, 2008.

Drożdż, Michał. „Inny jako osoba. Personalistyczny paradygmat aksjologii komunikowania międzykulturowego w myśli i działaniu Jana Pawła II". Jan Pawet II w komunikowaniu międzykulturowym. O sztuce dialogu z Innym, red. nauk. Arkadiusz Dudziak, Agnieszka Żejmo, Vertum Wydawnictwo Naukowe i Specjalistyczne, 2014, ss. 11-53.

Dudziak, Arkadiusz. „Aksjologiczne aspekty komunikowania międzykulturowego Jana Pawła II”. Jan Pawet II w komunikowaniu międzykulturowym. O sztuce dialogu z Innym, red. nauk. Arkadiusz Dudziak, Agnieszka Żejmo, Vertum Wydawnictwo Naukowe i Specjalistyczne, 2014, ss. 120-142.

Dudziak, Arkadiusz. „Aksjologiczne aspekty komunikowania św. Jana Pawła II w orędziach na Światowy Dzień Środków Społecznego Przekazu”. Media a wartości. Człowiek w mediach, red. Monika Gabryś-Sławińska, Katarzyna Pilipiuk, Podlaska Fundacja Wspierania Talentów w Białej Podlaskiej, 2016, ss. 198-209.

Dudziak, Arkadiusz. „W kręgu komunikacji aksjologicznej św. Jana Pawła II na przykładzie wystąpienia w Balicach w 2002 roku”. Prace Językoznawcze, t. XVIII, nr 1, 2016, ss. 49-59.

Elzenberg, Henryk. „Wartość ujemna”. Studia Filozoficzne, nr 12, 1986, ss. 23-28. 
Hostyński, Lesław. O wartościach. Aksjologia formalna, estetyka i etyka Henryka Elzenberga. Wydawnictwo Uniwersytetu Marii Curie-Skłodowskiej, 1991.

Kiklewicz, Aleksander. „Lingwistyczne aspekty kategorii wartości”. Wartości i wartościowanie we współczesnej humanistyce. III: Perspektywa językoznawcza, red. Aleksander Kiklewicz, Jolanta Piwowar, Centrum Badań Europy Wschodniej UWM w Olsztynie, 2017, ss. 33-72.

Kurczab, Henryk. „Z problemów wartości i wartościowania (wybrane zagadnienia)”. Zeszyty Naukowe URz, Seria Filologiczna z. 72, Dydaktyka 7, 2012, ss. 7-37.

Laskowska, Elżbieta. Wartościowanie w języku potocznym. Wydawnictwo Uniwersytetu Kazimierza Wielkiego, 1992.

Leszczak, Oleg. „Metodologiczne zasady wartościowania i wartość jako koncept metodologiczny”. Dialog - Komparatystyka - Literatura, red. Edward Kasperski, Danuta Ulicka, Oficyna Wydawnicza ASPRA, 2002, ss. 35-65.

Łabaszczuk, Michał. „Językowe środki wyrażania wartości (podstawy metodologiczne)”. Antynomie wartości. Problematyka aksjologiczna w językoznawstwie, red. Agnieszka Oskiera, Wydawnictwo Wyższej Szkoły Humanistyczno-Ekonomicznej w Łodzi, 2007, ss. 9-18.

Obacz, Piotr. „Psychologia humanistyczna: humanistyczne ideały i wartości w psychologii”. Idee i wartości w języku i kulturze, red. nauk. Iza Matusiak-Kempa, Alina Naruszewicz-Duchlińska, Instytut Filologii Polskiej Uniwersytetu Warmińsko-Mazurskiego w Olsztynie, 2015, ss. 62-71.

Przestrzeń słowa. Twórczość literacka Karola Wojtyły - Jana Pawła II, red. Zofia Zarębianka i Jan Machniak, Wydawnictwo św. Stanisława BM, 2006.

Puzynina, Jadwiga. „Problemy wartościowania w języku i w tekście”. Etnolingwistyka. Problemy języka i kultury, 16, red. Jerzy Bartmiński, Wydawnictwo Uniwersytetu Marii Curie-Skłodowskiej, 2004, ss. 179-189.

Rahner, Karl, i Herbert Vorgrimler. Mały stownik teologiczny. Przeł. Tadeusz Mieszkowski i Paweł Pachciarek, Instytut Wydawniczy PAX, 1987.

Ricoeur, Paul. Egzystencja i hermeneutyka. PAX, 1985.

Ricoeur, Paul. Język, tekst, interpretacja. Państwowy Instytut Wydawniczy, 1989.

Riceour, Paul. O interpretacji. Esej o Freudzie. Wydawnictwo KR, 2009.

Szocik, Konrad. Jana Pawła II idee filozoficzne. Między ortodoksja a sekularyzacją. Wydawnictwo Wyższej Szkoły Informatyki i Zarządzania w Rzeszowie, 2005.

Wojtyła, Karol. Dzieła literackie i teatralne, t. 1: Juwenilia (1938-1946), red. Jacek Popiel i in., Znak, 2019.

Wojtyła, Karol. Elementarz etyczny. Towarzystwo Naukowe Katolickiego Uniwersytetu Lubelskiego, 1999.

Wojtyła, Karol. Poezje, dramaty, szkice. Jan Paweł II. Tryptyk rzymski. Wstęp Marek Skwarnicki, Znak, 2004.

Wojtyła, Karol. Rozważania o istocie człowieka. Wydawnictwo WAM, 2003.

Zgółka, Tadeusz. Język wśród wartości. Wydawnictwo Poznańskie, 1988.

\author{
PSAETERZ DAWIDÓW (KSIĘGA SEOWIAŃSKA) \\ ORAZ ELEMENTARZ ETYCZNY KAROLA WOJTYŁY \\ JAKO PRZEJAWY KOMUNIKOWANIA IDEI I WARTOŚCI
}

Streszczenie

Tematyka artykułu dotyczy zależności pomiędzy aksjosferą wczesnej poezji Karola Wojtyły a jego preferencjami aksjologicznymi w późniejszym okresie twórczej aktywności. Przedmiot badań stanowią: cykl poetycki Psalterz Dawidów (Księga słowiańska) z 1939 roku oraz Elementarz etyczny z lat 
1957-1958. Do analizy idei w tekstach zastosowano hermeneutykę, zaś do analizy wartości - metodę aksjolingwistyczną. Badanie tekstów umożliwia odtworzenie systemu wartości preferowanych przez Karola Wojtyłę - poetę i filozofa. System ten wpisuje się w aksjologię chrześcijańskiego humanizmu.

Słowa kluczowe: Karol Wojtyła; hermeneutyka; aksjolingwistyka; aksjologia chrześcijańskiego humanizmu; idea; wartość

THE PSALTER OF DAVID (THE SLAVONIC BOOK)

AND THE ETHICAL PRIMER OF KAROL WOJTYŁA AS A MANIFESTATION OF THE COMMUNICATION OF IDEAS AND VALUES

Sum mary

The subject of this article concerns the relationship between the axiosphere of Karol Wojtyła's early poetry and his axiological preferences in the later period of his creative activity. The subject of the research are the poetic cycle The Psalter of David (The Slavonic Book) from 1939 and The Ethical Primer from 1957-1958. Hermeneutics was used in the analysis of ideas, while the axiolinguistic method was employed in the analysis of the values. The study of these texts makes it possible to recreate the system of values preferred by Karol Wojtyła as a poet and philosopher. This system is part of the axiology of Christian humanism.

Keywords: Karol Wojtyła; hermeneutics; axiolinguistics; axiology of Christian humanism; idea; value 